\title{
КУЛЬТУРНИЙ ПОЛІЦЕНТРИЗМ УКРАЇНСЬКОГО ЕТНОСУ І ПРОБЛЕМА НАЦІОНАЛЬНОЇ ІДЕНТИФІКАЦІЇ
}

\begin{abstract}
О.А. Моргун
Для будь-якої поліетнічної країни встановлення об'єктивних передумов формування національної свідомості $є$ надзвичайно важливим компонентом національної ідентифікації. Актуальною для України проблемою $є$ дослідження процесів формування свідомості тих вихідних етносів, які пізніше утворили ядро української національної свідомості, такої розмаїтої та багатовекторної. Дослідження цих етносів може здійснюватись як на матеріальному територіальному підгрунті, так і на духовних соціально-філософських засадах. Досить актуальною є проблема визначення етнічних регіонів і соціально-територіальних спільнот як конкретних носіїв національного прогресу, перш за все, у контексті виявлення соціально-філософських засад формування української національної свідомості як феномена національної і європейської культури. Регіональні різновиди до середини $90-\mathrm{x} \mathrm{ро-}$ ків минулого століття зазвичай пов'язувалися з економічним аспектом формування територіально-виробничих комплексів. Тобто з виникненням економічної свідомості або, за дещо іншою термінологією, індустріальної свідомості. В сучасних інформаційних суспільствах така свідомість отримує назву постіндустріальної свідомості. Але вже наприкінці 90-х років з поглибленням процесів соціально-економічної трансформації в Україні тенденція до регіоналізації розглядається як соціально-політичний феномен і важливий фактор суспільного розвитку, що також зумовлює формування загальнонаціональної суспільної свідомості. Етнорегіональна спільнота поступово формує мету свого
\end{abstract}

Актуальні проблеми духовності:

зб. наук. праць / Ред.: Я.В. Шрамко

Вип. 10. - Кривий Ріг, 2009, 335-339

335 
духовного, соціально-економічного і політичного розвитку, яка яскраво відображається в її інтересах та ідеалах. На початку ХХІ століття основним чинником формування національної свідомості $є$ так звана «етнорегіональна свідомість». При цьому, формування етнорегіональної свідомості обумовлюється не тільки економічними чинниками та соціально-політичною трансформацією суспільства, але і кризою індустріалізації і необхідністю створення відповідних умов для постіндустріального розвитку суспільства. Актуальним також є підняття суспільної свідомості з регіонального рівня на виміри національні і навіть транснаціональні. Практична ж реалізація цього можлива тільки за умов дослідження історичних глибин формування української етнічної культури. Сучасні етнологічні дослідження все більше звертаються до історичної етнології, вибудовуючи комплексний підхід до культури на основі об'єднання ціннісного, діяльнісного та адаптаційно-діяльнісного підходів [5, с.88-91]. Це значно наближає класичну етнологію до осмислення етногенезу на основі історико-філософської методології. Автор монографії «Етнологія України» Г. Лозко слушно відмічає, що для адекватного висвітлення національного етногенезу треба «виробити свій власний погляд на нашу минувшину, щоб відокремити з великого розмаїття культур саме те, що є нашим власним, саме - українським» [4, с. 10-11]. Більш того, український культуролог І. Лисяк-Рудницький чітко визначив ключову роль української нації в духовному творенні східноєвропейської культури [3, с. 524-541].

Для визначення першоджерел української національної свідомості необхідно окреслити відповідне філософсько-методологічне підгрунтя. Для відтворення повноцінної картини формування давньої етнічної свідомості України та її подальшого етногенезу як основного чинника формування національної свідомості застосовні різноманітні методи, серед яких можна виокремити лінгвістичний аналіз, суто етнографічний підхід, аналіз історичних першоджерел, які дають матеріали для комп'ютерного моделювання. Але для комплексної реконструкції історії первісного суспільства потрібна не стільки репрезентативність історичних матеріалів, але й соціально-філософське осмислення істоpiï. Для соціально-філософського аналізу історичного процесу достатньо в першому наближенні виділити матеріально-виробничі особливості історичної культури, основні способи соціальної організації та духовного життя і на цій основі зафіксувати сутнісні ознаки етнічної культури. Таким чином, можемо виділити наступні основні культурні характеристики на території, яку деякі дослідники називають «протоукраїнським ареалом». 
За матеріальним способом суспільного виробництва. Середньодніпровська (придніпровська) і трипільська культури мають усі ознаки переходу від привласнюючого виробництва до виробництва відтворювального внаслідок «неолітичної революції». Сама природна продуктивність землеробської праці наших предків, які практикували спільнообщинний та сусідсько-сімейний труд, вже забезпечувала його прибутковість і гарантоване існування. Це вже був єдиний процес спільної праці членів общини в поєднанні з присадибним господарюванням, що вело до осілості, сталості і заможності [7, с. 252]. На цій основі формувався суспільнокорисний спосіб життєдіяльності з виробничо-трудовою свідомістю працелюбності.

За способом соціальної організації. Осілий спосіб життя, укорінений в общинно-родове і сімейне господарство, родоплемінна організація з домінуванням патріархальних відносин та парних шлюбів. Подібна соціальна організація в поєднанні з безперервним поширенням землеробсько-скотарського господарювання розвинулась у сільську общину (а згодом у селища і характерні для України городища).

За способом духовного життя. Природний синкретизм світобачення предків українців з часом переростає у свідомість суспільнопрактичного напрямку. Крім того, слід зазначити, що у етносів, які населяли територію сучасної України, семантика менталітету і семантика культури багато в чому збігалися [2, с. 240-241].

Таким чином, виходячи з соціально-філософської методології осмислення культурно-історичних процесів творення етнічної свідомості, можна встановити такі головні критерії аналізу.

Перший критерій первісно-матеріальних археологічних свідчень, які грунтуються на археологічних пам'ятках, знайдених при розкопках прадавніх поселень, святилищ та поховань на територіях, домінуючих у культурно-історичному відношенні (як найстаріші центри культури).

Другий критерій соціокультурної динаміки етносів. Він ураховуе територіальне розселення, укорінення та набуття сталості в життедіяльності, пов'язаних, за Л. Гумільовим, з формуванням генералізованих і фіксованих етносів з історичним ім'ям-етнонімом, субетносів та суперетносів. Щодо філософсько-методологічної бази для подібного дослідження Гумільов висловлює таку думку: «Оскільки ми виходимо з того, що етнос у своєму становленні-феномен природний, то основою його вивчення може бути тільки філософія природознавства. Але це повинна бути така філософія природознавства, що виходить на спонтанний розвиток соціальних форм через суспільно-економічні формації» [1, с. 16, 18]. 
Tретій критерій зв'язку етнічних культур та народів одного етнічного коріння. У цьому зв'язку культура постає як безперервний процес трансцендентування, в якому здійснюється вихід людини за межі особистісного «життєвого світу». Аналогічним чином проявляє себе i трансценденція культури, яка встановлюється і відтворюється через споріднені форми етнічної свідомості.

Четвертий критерій духовно-формаційного розвитку етнічних культур у значенні культурно-формаційних систем. Це критерій виділення первісних соціокультурних формацій, що заглиблені в історію.

Критерій первісно-матеріальних археологічних свідчень вважається основним стосовно надійності, достовірності і матеріальної предметності. Саме за ним фіксується факт історичного існування етнічної культури та рівень її розвитку. На основі аналізу цих археологічних пам'яток дослідники роблять певні висновки щодо матеріального, соціального та духовного життя наших пращурів, їх світогляду, особливостей свідомості. Функціональне обмеження археологічних досліджень полягає в тому, що в історико-філософському осмисленні вони не йшли далі фіксування епох кам'яного віку, міді, бронзи, заліза, макролітичних і мегалітичних свідоцтв прадавніх культур. Були намагання привнести в подібну класифікацію побутові фактори розвитку: кам'янний вік, передкерамічний (передгончарний) період, гончарний, регіонально-гончарний (локальний) і класично-гончарний період (загальнокультурний).

На територіях проживання сучасного українського етносу проведено достатньо відповідних археологічних досліджень. Вони дають право на наукових підставах засвідчити пріоритетність культури степового неоліту в регіоні від Карпат до Нижнього Уралу, а на Півдні - до Кавказу [6]. Центр знаходився у Середньому Придніпров’ї, де набагато раніше від інших регіонів сформувалась і розвивалась землеробськопромислова культура відтворювального типу з високим ступенем життєдіяльності.

Отже, ми стверджуємо головну особливість української свідомості - її творчо-відтворювальний характер, що своїм матеріальним підгрунтям має відтворювально-господарський базис суспільної життєдіяльності. Культурно-історичні трансформації українського суспільства та встановлений характер змін у світобаченні етносів на шляху їх розвитку дає нову можливість встановити об'єктивні передумови формування історичної культури національної свідомості з подальшим полегшенням її ідентифікації. Такий підхід формує єдине розуміння історичного та культурного розвитку національної свідомості, що створює 
основу для успішної ідентифікації національного світогляду українства.

\section{1 Бібліографія}

[1] Гумилев Л. Этногенез и биосфера Земли.-М.: АСТ, 2002.

[2] Колмаков В.Ю. Семантика менталитета // Современная этнопсихология. - Минск: Харвест, 2003.

[3] Лислк-Рудницький I. Воля України в Новітній історії // Історія філософії України. - К.: Либідь, 1993.

[4] Лозко Г. Етнологія України. - К.: Арт. Ек, 2001.

[5] Макарчук C., Турій С. Український етнос. - Львів, 1990.

[6] Павленко Ю.В. Этнос как социальная система. Новые методы археологических исследований. - К., 1982.

[7] Румянцев A.M. Первобытный способ производства.- М.: Наука, 1987. 